\title{
THE UNITED NATIONS CONVENTION ON THE RIGHTS OF PERSONS WITH DISABILITIES IN CANADIAN AND AMERICAN JURISPRUDENCE
}

\section{Ravi Malhotra*}

In this paper, I explore the still evolving jurisprudence with respect to the Convention on the Rights of Persons with Disabilities [CRPD] in Canada and the United States. I argue that the Canadian disability rights movement has always been open to insights from international law. Although the 1990 passage of the landmark Americans with Disabilities Act [ADA] has had an impact internationally as other countries enact similar legislation, the CRPD, which the United States Senate has yet to ratify, has played a marginal role to date in American courts. It remains to be seen if a more robust judicial dialogue can be fostered between the CRPD and domestic courts in both countries.

Dans le présent document, j'explore la jurisprudence toujours en évolution au sujet de l'application de la Convention relative aux droits des personnes handicapées [CDPH] au Canada et aux États-Unis. Je soutiens que le mouvement canadien de défense des droits des handicapés a toujours été ouvert aux points de vue émanant du droit international. Bien que l'adoption, en 1990, de la loi clé intitulée Americans with Disabilities Act [ADA] ait eu des répercussions à l'échelle internationale, puisque d'autres pays ont adopté des lois similaires, la $C D P H$, que le Sénat américain n'a pas encore ratifiée, a joué un rôle marginal jusqu'à maintenant devant les tribunaux américains. Il reste à déterminer s'il est possible de promouvoir un dialogue judiciaire plus vigoureux entre les organes qui appliquent la CDPH et les tribunaux nationaux des deux pays.

\section{INTRODUCTION}

In this brief paper, I explore the emerging jurisprudence in Canada and the United States relating to the United Nations Convention on the Rights of Persons with Disabilities $[C R P D]^{1}$. Opened for signature in 2006 and coming into force in 2008, the CRPD was the fastest negotiated United Nations treaty in history and has the potential to transform the lives of the hundreds of millions of people with disabilities worldwide. ${ }^{2}$ In the North American context, it remains the case that

\footnotetext{
* Associate Professor, Faculty of Law, Common Law Section, University of Ottawa. I thank Arlene Kanter and the peer reviewers for their invaluable feedback. I also thank Laverne Jacobs for inviting me to attend the Berkeley Symposium. All remaining errors are my responsibility.

1 Convention on the Rights of Persons with Disabilities, GA Res 61/106 UNGAOR, $61^{\text {st }}$ Sess, Supp No 49, UN Doc Annex: Convention on the Rights of Persons with Disabilities A/Res61/106 (2007) 2 [CRPD]

2 National Commission Persons with Disability KNPD-Malta, "Working Towards the Implementation of the UNCRPD" online: Kummissjoni Nazzjonali Persuni b'Diżabilità <http://www.knpd.org> at 4; Gerard Quinn, “A Short Guide to the United Nations Convention on the Rights of Persons with Disabilities" in Gerard Quinn \& Lisa Waddington, eds, European Yearbook of Disability Law, Vol 1 (Antwerp: Intersentia, 2009) 89 at 89.
} 
people with disabilities remain systematically marginalized in both Canada and the United States with respect to employment, transportation and education. ${ }^{3}$ The $C R P D$ was ratified by Canada in 2010 but, at the time of writing, the United States Senate has unfortunately yet to ratify the Convention. ${ }^{4}$ The CRPD sets out various rights empowering people with disabilities respecting education, health, and work and employment, and other spheres. It builds on earlier initiatives to promote equality for people with disabilities such as the 1993 Standard Rules for the Equalization of Opportunities for Persons with Disabilities ${ }^{5}$ and the 1994 General Comment No. 5 of the Committee on Economic, Social and Cultural Rights on disability. ${ }^{6}$ It is also in keeping with the social model of disablement that focuses on transforming societal barriers so as to create an inclusive society where people with disabilities may flourish. ${ }^{7}$ Using the landmark work of legal scholars Harold Koh and Melissa Waters on transnational legal process and transnational judicial dialogue theory, I examine how the $C R P D$ has been applied in the case law and assess its potential for social transformation in the two countries. I explore whether we may ultimately see a convergence between domestic disability rights law in Canada and the United States and the principles so eloquently enunciated in the CRPD. While CRPD jurisprudence is in its infancy, I also consider why the $C R P D$ to date has seemingly had more purchase in Canada than in the United States, specifically analyzing the competing schools of thought relating to the legal requirements for treaty implementation. I suggest, however, that the entire history of disability rights in Canada has always been influenced by international developments since at least the 1970s, especially the International Year of Disabled Persons declared by the United Nations in 1981. This contrasts with the much more domestic orientation of American activists with disabilities who fought for increased wheelchair access in the aftermath of the Vietnam War and later the adoption of the Americans with Disabilities Act of 1990 [ADA]. ${ }^{8}$ This more overt international orientation in Canada has implications for future judicial attitudes toward interpretation of the CRPD. In Part II, I provide an overview of the CRPD. In Part III, I explain transnational legal process and transnational judicial dialogue theory as developed respectively by Professors Harold Koh and Melissa Waters and offer some tentative suggestions about why the $C R P D$ has had more purchase in Canada. In Part IV, I explore Canadian and American cases

3 Ravi Malhotra, "A Tale of Marginalization: Comparing Workers with Disabilities in Canada and the United States" (2009) 22 J L \& Soc Pol'y 79.

4 Canada, Convention on the Rights of Persons with Disabilities: First Report of Canada (Ottawa, 2014) at para 1; "GOP Thwarts US Senate CRPD Ratification AGAIN", online: GlobalPartnersUnited <http://www.globalpartners-united.com/news/gop-thwarts-us-senate-crpd-ratification-again $>$. The newly elected Republican majority in the Senate in the 2014 midterm elections further diminishes the likelihood of ratification in the near future.

5 GA Res 48/96, UNGAOR $48^{\text {th }}$ Sess, UN Doc A/RES/48/96 (1994).

6 Quinn, supra note 2 at 96.

7 The literature on the social model is voluminous and the debates amongst theorists of the social model are beyond the scope of this paper. For a canonical treatment, see Michael Oliver, The Politics of Disablement (London: Macmillan, 1990) and Michael Oliver \& Colin Barnes, The New Politics of Disablement (London: Macmillan, 2012).

8 Pub L No 101-336, 104 Stat 327 (1990) (codified at 42 USC § 12101-12213 and scattered sections of 29, 47 USC) (ADA). 
that have applied, interpreted or discussed the CRPD. In Part V, I offer some tentative conclusions.

\section{THE CONVENTION ON THE RIGHTS OF PERSONS WITH DISABILITIES}

The CRPD originates in a 2001 General Assembly resolution ${ }^{9}$ which established an ad hoc committee to evaluate proposals for a possible Convention on disability rights and whether such a Convention was warranted. Mexico championed the issue early on. ${ }^{10}$ As there has been little consideration of disability discrimination under the existing UN Conventions, many state parties were convinced of the need for a Convention after a presentation by the then High Commissioner on Human Rights, Mary Robinson. ${ }^{11}$ It should also be noted that disability rights advocacy organizations played a significant role in arguing for the need for a thematic Convention and in the debates during drafting of the CRPD. Nearly a hundred disability and allied NGOs came together to form the International Disability Caucus [IDC] to more effectively influence the process. ${ }^{12}$ The IDC was effective in inserting strong anti-discrimination provisions, as well as provisions that encompass other areas of life that affect people with disabilities. ${ }^{13}$

The $C R P D$ embodies principles derived from both traditional civil and political rights and social, cultural and economic rights. In that sense, by bridging this historic divide within the world of international human rights, it is a very fitting testament to international human rights law in the $21^{\text {st }}$ century. ${ }^{14}$ Although the stakeholders agreed that the CRPD was not creating new rights, in practice, certain provisions of the Convention, such as Article 26 on a right to habilitation and rehabilitation, inevitably entailed new concepts as they are devoted to issues of concern primarily to people with disabilities. ${ }^{15}$ Article 1 affirms that the purpose of the Convention is to promote and protect the rights of people with disabilities in a manner consonant with their dignity. ${ }^{16}$ It also sets out a definition of disability that is broad and comprehensive. It states: "[p]ersons with disabilities include those who have long-term physical, mental, intellectual or sensory impairments which in interaction with various barriers may hinder their full and effective participation in society on an equal basis with others." ${ }^{17}$ As Trömel has noted, this may warrant revision of the definition of disability by those state parties that have utilized a more narrow definition. ${ }^{18}$ Although the Canadian definition of disability has tended to be

9 Comprehensive and Integral International Convention to Protect and Promote the Rights and Dignity of Persons with Disabilities, GA Res 56/198 UNGAOR $56^{\text {th }}$ Sess, UN Doc A/RES/56/168 (2001).

10 Stefan Trömel, "A Personal Perspective on the Drafting History of the United Nations Convention on the Rights of Persons with Disabilities" in Quinn \& Waddington, supra note 2, 115 at 116.

11 Ibid. See also Quinn, supra note 2 at 93.

12 Trömel, supra note 10 at 117 . Hence, disability organizations affiliated with the IDC provided a common slate for the working group that produced the draft Convention.

13 Ibid at 118.

14 Ibid at 118. The Convention on the Rights of the Child offers another example of this paradigm but is more detailed. On this point, see Quinn, supra note 2 at 99.

15 Trömel, supra note 10 at 118-19.

16 CRPD, supra note 1 at Art 1.

17 Ibid.

18 Trömel, supra note 10 at 122. 
broad, ${ }^{19}$ American courts have struggled with the definition of disability under the ADA for years, eventually leading Congress to pass legislation to require courts to use a broader definition. ${ }^{20}$ How successful that intervention will be remains to be seen, suggesting that Article 1 of the CRPD could be, upon future ratification by the United States Senate, used to bolster legal arguments for a broader definition of disability in American courts.

Trömel has usefully classified the substantive provisions of the Convention into five categories: rights that protect the person; rights that restore autonomy, choice and independence; rights of access and participation; liberty rights; and economic, social and cultural rights. ${ }^{21}$ Rights that protect the person would encompass the right to life contained in Article 10; freedom from torture, inhuman or degrading treatment or punishment in Article 15; freedom from violence, abuse and exploitation in Article 16; and a right to integrity of the person in Article $17 .^{22}$ Article 16 will hopefully address the long history of violence that has plagued institutions which have housed people with disabilities. ${ }^{23}$ Rights that restore autonomy, choice and independence include the pivotal right of equal recognition before the law contained in Article 12, the right of habilitation and rehabilitation contained in Article 26, the right to freedom of expression including a right to information in accessible formats in Article 21, the right to privacy in Article 22, and respect for the home and the family in Article $23 .{ }^{24}$ Such rights facilitate the exercise of more general human rights in the specific context of disability. For instance, Article 21 bolsters a general right to freedom of expression to ensure barriers do not preclude the participation of blind people who require materials in alternative formats or Deaf people who may require sign language interpretation in order to fully participate in public life. ${ }^{25}$ Rights of access and participation include a very broad commitment to accessibility in Article 9, rights to participation in political and public life in Article 29, rights to cultural life, recreation, leisure and sport in Article 30 and access to the justice system in Article 13. ${ }^{26}$ Liberty rights include a general right to liberty which shall not be forfeited unlawfully or arbitrarily in Article 14, the right of personal mobility in Article 20, and liberty of movement and nationality in Article $18 .^{27}$ Finally, economic, social and cultural rights encompass a right to education in

19 Michael Lynk, "Disability and the Duty to Accommodate: An Arbitrator's Perspective" [2001-02] Lab Arb YB 51 at 61-64.

20 Alex B Long, "Introducing the New and Improved Americans with Disabilities Act: Assessing the ADA Amendments Act of 2008" (2008) 103 Nw UL Rev 217. For a discussion of the problems with the definition of disability prior to the passage of the ADA Amendments Act, see Samuel R Bagenstos, Law and the Contradictions of the Disability Rights Movement (New Haven: Yale University Press, 2009) at ch 3.

21 Quinn, supra note 2 at 104.

22 CRPD, supra note 1 at Art 10, Art 15, Art 16, Art 17.

23 A classic study is Dick Sobsey, Violence and Abuse in the Lives of People with Disabilities: The End of Silent Acceptance? (Baltimore: Paul H Brookes, 1994). A more recent treatment is Liat Ben-Moshe, Chris Chapman \& Allison C Carey, Disability Incarcerated: Imprisonment and Disability in the United States and Canada (London: Palgrave Macmillan, 2014).

24 CRPD, supra note 1 at Art 12, Art 26, Art 21, Art 22, Art 23.

25 Quinn, supra note 2 at 106-07.

26 CRPD, supra note 1 at Art 9, Art 29, Art 30, Art 13.

27 Ibid at Art 14, Art 20, Art 18. 
Article 24, a right to work in Article 27, the right to an adequate standard of living in Article 28 and a right to health in Article $25 .^{28}$

Although not applicable to either Canada or the United States, the Optional Protocol should be briefly mentioned. The Optional Protocol allows nationals of state parties which have signed it to make individual or collective complaints against state parties to the Committee on the Rights of Persons with Disabilities. ${ }^{29}$ The Committee, consisting of eighteen experts elected to a four year term and authorized by Article 34, also monitors reports of state parties, analyzes shadow reports issued by organizations of people with disabilities, issues General Comments and Recommendations, and prepares a biennial report for the General Assembly. ${ }^{30}$ In 2014, the Committee issued two General Comments to guide the Committee's work. General Comment No. 1 features the delineation of the principles underlying Article $12^{31}$ and General Comment No. 2 is devoted to articulating the principles underlying Article $9 .{ }^{32}$ I turn now to discuss transnational legal process and transnational judicial dialogue theory as developed by Harold Koh and Melissa Waters and how it may shed light on the CRPD and its implications for Canadian and American disability rights law.

\section{TRANSNATIONAL LEGAL PROCESS AND TRANSNATIONAL JUDICIAL DIALOGUE THEORY}

Harold Koh has defined transnational legal process as "the theory and practice of how public and private actors - nation-states, international organizations, multinational enterprises, nongovernmental organizations, and private individuals - interact in a variety of public and private, domestic and international fora to make, interpret, enforce, and ultimately, internalize rules of transnational law." ${ }^{33}$ Koh identifies four key features of transnational legal process. First, it is non-traditional. It dissipates the boundaries between public and private law and between international and domestic law. Second, it is non-statist. The actors involved include many organizations, including non-governmental organizations that are not state actors. At the same time, transgovernmental networks consisting of peer to peer dialogue between administrative agencies across boundaries are growing. The rise of transgovernmental networks has been attributed by Kal Raustiala to technological innovation, the expansion of domestic regulation and

28 Ibid at Art 24, Art 27, Art 28, Art 25. For a detailed discussion of the relevance of Article 24 in the Canadian context, see Ravi Malhotra \& Robin F Hansen, "The United Nations Convention on the Rights of Persons with Disabilities and its Implications for the Equality Rights of Canadians with Disabilities: The Case of Education" (2011) 29:1 Windsor YB Access Just 73.

29 Michael A Stein \& Janet E Lord, "Monitoring the Convention on the Rights of Persons with Disabilities: Innovations, Lost Opportunities, and Future Potential” (2010) 32 Human Rts Q 689 at 697.

30 Ibid at 694-96.

31 General Comment No 1,Committee on the Rights of Persons with Disabilities $11^{\text {th }}$ Sess (19 May 2014) $\mathrm{CRPD} / \mathrm{C} / \mathrm{GC} / 1$, available online: UN Office of the High Commissioner for Human Rights $<$ http://daccess-ddsny.un.org/doc/UNDOC/GEN/G14/031/20/PDF/G1403120.pdf?OpenElement>.

32 General Comment No 2 Committee on the Rights of Persons with Disabilities, (22 May 2014) CRPD/C/GC/1, available online: UN Office of the High Commissioner for Human Rights $<$ http://daccess-ddsny.un.org/doc/UNDOC/GEN/G14/033/13/PDF/G1403313.pdf?OpenElement>.

33 Harold Hongju Koh, "Transnational Legal Process" (1996) 75 Neb L Rev 181 at 183-84. 
the rise of globalization. ${ }^{34}$ Third, transnational legal process is dynamic. It transforms itself as it shifts from the public to the private and from the international to the world of domestic law. Finally, it is normative. As the interactive process reaches fruition, new rules of law are formulated and internalized. Their application and interpretation initiates the process all over again. ${ }^{35}$ While it is too early to fully document this process for the relatively new CRPD, one can see how non-state actors, such as non-governmental organizations, have been playing a pivotal role in shaping both the CRPD and state responses to its enactment. In Canada, for instance, the Council of Canadians with Disabilities [CCD], the leading cross-disability rights organization, is currently working on a shadow report critiquing Canada's submission to the Committee on the Rights of Persons with Disabilities reporting on its compliance. ${ }^{36}$ Numerous disability organizations internationally have also commented on the compliance of their home countries and suggested ways in which greater compliance may be achieved. ${ }^{37}$ One hopes that this leads, over time, to the kind of dynamic dialogue which results in real change for people with disabilities.

Melissa Waters has built on Koh's work to argue for what she calls transnational judicial dialogue. ${ }^{38}$ Writing in the context of highly controversial American policies on the death penalty, she argues that most scholarship has focused on the internalization of international norms by the courts of domestic states to ensure state compliance with a state's international legal responsibilities. Even states where the death penalty has long been abolished are forced to situate their rulings within the international legal framework when contemplating whether to extradite a person to a jurisdiction where he or she may face the death penalty. ${ }^{39}$ Waters argues that it is more fruitful to consider how domestic courts simultaneously shape over time the content of

34 Kal Raustiala, "The Architecture of International Cooperation: Transgovernmental Networks and the Future of International Law" (2002) 43:1 Va J Int'1 L 1 at 16. However, Raustiala acknowledges that international cooperation by administrative agencies has been largely confined to issue areas such as economic and environmental regulation, rather than labour or human rights. See ibid at 15.

35 Koh, supra note 33 at 184 . Waters accordingly notes three stages in transnational legal process: interaction, interpretation and internalization. See Melissa A Waters, "Mediating Norms and Identity: The Role of Transnational Judicial Dialogue in Creating and Enforcing International Law" (2005) 93:2 Geo LJ 487 at 500.

36 "CCD Chairperson's Update - Highlights of June 2014 Council Meeting”, online: Council of Canadians with Disabilities <http://www.ccdonline.ca/en/publications/chairpersons-update/2014/Council>. Canada's First Report on the CRPD may be found at Government of Canada, "Convention on the Rights of Persons with Disabilities: First Report of Canada", online: Council of Canadians with Disabilities

$<$ http://www.ccdonline.ca/media/international/Convention $\% 20$ on $\% 20$ the $\% 20$ Rights\%20of\%20Persons\%20with\%20Disabilities\%20-\%20First\%20Report\%20of\%20Canada.pdf>.

37 See e.g. the documents collected in Deborah A Ziegler, Inclusion for All: The UN Convention on the Rights of Persons with Disabilities (New York: IDebate Press, 2010).

38 Waters, supra note 35. For a take on dialogue in this context from a distinguished Canadian jurist, see The Honourable Claire L'Heureux-Dubé, "The Importance of Dialogue: Globalization and the International Impact of the Rehnquist Court" (1998) 34:1 Tulsa LJ 15. Of course, Professor Hogg and Allison Bushell have famously used this metaphor to discuss the relationship between domestic courts and legislatures. See Peter W Hogg \& Allison A Bushell, "The Charter Dialogue Between Courts and Legislatures (or Perhaps the Charter of Rights Isn't Such a Bad Thing After All)" (1997) 35 Osgoode Hall LJ 75.

39 Waters, supra note 35 at 510-11. 
international legal norms. In other words, she regards the relationship between domestic and international norms as co-constitutive. ${ }^{40}$

Waters also outlines two key concepts that are crucial for understanding how transnational judicial dialogue works: norm export and norm convergence. ${ }^{41}$ Legal norms are important not solely because of the possibility of sanction but because the expression of legal norms can guide behaviour by influencing expectations of parties. ${ }^{42}$ Norm export occurs when domestic courts champion a particular norm at the transnational level. It is then picked up by other transnational actors and, eventually, becomes an international norm through the soft power exercised. ${ }^{43}$ Norm convergence occurs when domestic and international law converge on a single global normative standard. ${ }^{44}$ Waters identifies three key reasons for norm convergence. First, repeated success at norm export may eventually result in a sufficient number of domestic states adopting the norm to create norm convergence. Second, a particularly pressing policy problem may motivate domestic courts and other transnational actors to seek a common international standard. Finally, the greater contact among jurists internationally allows for the possibility of greater understanding across national boundaries and a cross-fertilization of ideas. In the long term, such contacts, facilitated greatly by recent innovations such as the internet and the relative ease of global travel, may lead to norm convergence. ${ }^{45}$

Although it is undoubtedly true that the use of international law has remained intensely controversial in American courts and the United States has not ratified the $C R P D,{ }^{46}$ this has not precluded American developments in disability rights law from having an impact internationally. The landmark passage of the ADA arguably inspired the passage of more or (sometimes much) less analogous statutes in numerous other jurisdictions including Australia, Britain, Brazil, Costa Rica, Chile, Guatemala, Nicaragua and Peru. ${ }^{47}$ The Organization of American States enacted a regional convention prohibiting disability discrimination that came into effect in 2001 with a

$40 \quad$ Ibid at 501-02.

41 Ibid at 501-04.

42 Richard McAdams, "A Focal Point Theory of Expressive Law” (2000) 86 Va L Rev 1649 at 1651.

43 Waters, supra note 35 at 503. See also Judith L Goldstein et al, eds, Legalization and World Politics (Cambridge: The MIT Press, 2001).

${ }^{44}$ Ibid.

45 Ibid at 503-04.

46 See e.g. Bill Mears, "Justice Ginsburg Details Death Threat", online: CNN $<$ http://www.cnn.com/2006/LAW/03/15/scotus.threat/> (detailing death threats against Justices Ginsburg and O'Connor after citing international law in opinions); Tony Mauro, "Justice Ginsburg Says Death Threat Fueled by Dispute Over International Law", online: (2006) National Law Journal

$<$ http://www.nationallawjournal.com/id=900005449284/Justice-Ginsburg-Says-Death-Threat-Fueled-byDispute-Over-International-Law\#ixzz3Kboj6YfA>.

47 Robert L Burgdorf, Jr, "Disability Rights in the USA and Abroad" in Ziegler, supra note 37, 12 at 12-13; Rodrigo Jiménez, "The Americans with Disabilities Act and Its Impact on International and Latin-American Law" (2000) 52:1 Ala L Rev 419 at 420. On the other hand, a priority to analyzing American legal developments may marginalize the evolution of distinctive jurisprudence in other regional human rights systems. See e.g. African Commission on Human and People's Rights, Purohit and Moore v The Gambia, Communication No 241/2001, Sixteenth Activity report 2002-2003, Annex VII (ruling institutionalization of people with mental health issues in The Gambia violated numerous provisions of the African Charter on Human and Peoples' Rights). I thank Professor Kanter for drawing this case to my attention and for the idea. 
significant number of ratifications amongst Latin American states. The Inter-American Convention on the Elimination of All Forms of Discrimination Against Persons with Disabilities commits state parties to eliminate, gradually and to the extent possible, transportation, communication and architectural barriers faced by people with disabilities in areas such as employment, transportation, communication, housing, recreation, sports, law enforcement and administration of justice, and political and administrative activities. ${ }^{48}$ The decades of activism in the United States by disability rights advocates ultimately culminating in the passage of the ADA has consequently had an indirect effect in increasing awareness with respect to the rights of people with disabilities in other countries. ${ }^{49}$ In the Canadian context, where the inclusion of constitutional rights for people with disabilities predates the ADA by several years, the influence of international events such as the International Year of Disabled Persons (1981) in facilitating domestic legal change is clear. Both the inclusion of what was then termed "handicap" as a prohibited ground in the various human rights $\operatorname{codes}^{50}$ and the inclusion of disability as a prohibited ground in section 15 of the Charter of Rights and Freedoms ${ }^{51}$ in the early 1980s can be linked to the international law discourse around disability.

Institutional differences also account for the more positive reception of international law in Canada. Although a majority of the United States Supreme Court referred to a growing international consensus against the execution of people with disabilities in a death penalty case involving a defendant labelled as having intellectual disabilities in Atkins $v$ Virginia, ${ }^{52}$ the requirement of Senate ratification of international treaties by a stringent two-thirds majority in the United States pursuant to the Treaty Clause has posed a significant barrier to the consideration of the $C R P D$ which remains unratified in the United States. ${ }^{53}$ Ironically, as a monist state, once Senate ratification does occur, the treaty would take effect and be enforceable

48 "Inter-American Convention on the Elimination of All Forms of Discrimination against Persons with Disabilities", online: Department of International Law, Organization of American States

$<\mathrm{http}: / /$ www.oas.org/juridico/english/treaties/a-65.html $>$.

49 For an insightful overview of the American disability rights movement and its simultaneous use of activism and litigation strategies, see Doris Zames Fleischer \& Frieda Zames, The Disability Rights Movement: From Charity to Confrontation (Philadelphia: Temple University Press, 2001)

50 See e.g. Human Rights Code, RSO 1990, c H-19, s 5 (provincial human rights statute prohibiting employment discrimination in Ontario). However, it should also be noted that disability rights activists had to lobby for the inclusion of this ground. See David Lepofsky, "The Long, Arduous Road to a Barrier-Free Ontario for People with Disabilities: The History of the Ontarians with Disabilities Act — The First Chapter" (2004) 15 NJCL 125 at 140-44 (describing mobilization of Ontario disability rights activists to demand amendment of human rights code).

51 Part I of the Constitution Act, 1982, s 15, being Schedule B to the Canada Act, 1982 (UK), 1982, c 11 [Charter]. The original version of the Charter did not provide any protection for discrimination on the grounds of disability. Again, disability rights activists successfully mobilized to demand that the Charter be amended to prohibit disability discrimination. See Lepofsky, ibid at 144-46.

52 (2002) 536 US 304 at 11, n 21 (ruling 6-3 that the execution of people with intellectual disabilities violates the Eighth Amendment as cruel and unusual punishment).

53 US Const art II, $\S 2, \mathrm{cl} 2$. Other international treaties, such as the Convention on the Law of the Sea, have also been stymied as a result of the requirement for Senate ratification. See Sunil Kumar Agarwal, "Prospects of a Paradigm Shift in the American Policy Towards UN Convention on the Law of the Sea: Potential Implications “(April 15, 2011), online: Social Science Research Network <http://ssrn.com/abstract=1866113>. 
in American law. In Canada, as a dualist state, both ratification and implementing legislation by Parliament are required. ${ }^{54}$ The $C R P D$ was ratified by Canada in 2010 but no implementing legislation was ever enacted. However, Canadian courts have often demonstrated a flexible attitude in the interpretation of ratified international treaties, even in the absence of implementing legislation. ${ }^{55}$ For instance, the Supreme Court famously considered the unimplemented Convention on the Rights of the Child in Baker $v$ Canada (Minister of Citizenship and Immigration). ${ }^{56}$ In Baker, a majority of the Court, speaking through Justice L'Heureux-Dubé, ruled that it could consider Canada's obligations under the Convention of the Rights of the Child in the context of evaluating an application for a humanitarian and compassionate exemption to a deportation order against a mother with Canadian-born dependent children. The Court concluded that it was entitled to apply the values and principles of the Convention when considering the impact a deportation might have on the future well-being and best interests of the applicant's children. ${ }^{57}$

More recently, the Court has creatively used international law to significantly expand the scope of section 2(d) of the Charter in the context of a number of labour law decisions. ${ }^{58}$ In Dunmore v Ontario (Attorney General), ${ }^{59}$ the Court struck down an Ontario law which excluded agricultural workers from access to collective bargaining as unconstitutionally restricting their freedom of association. In reaching this conclusion, the Court cited, inter alia, ILO Convention No. 87 on the Freedom of Association and the Protection of the Right to Organize. ${ }^{60}$ A few years later, in the landmark decision, Health Services and Support-Facilities Subsector Bargaining Assn $v$ British Columbia, ${ }^{61}$ the majority overruled established case law and concluded that section 2(d) encompasses a procedural right to collective bargaining in a case where the British Columbia government unilaterally cancelled collective agreements. The Court recognized that international treaties could be used as a valuable interpretive tool in evaluating the scope of section 2(d) which offers protections at least as strong as international human rights law. It cited the International Covenant on Economic, Social and Cultural Rights (ICESCR), the International Covenant on Civil and Political Rights (ICCPR), and the ILO Convention No. $87 .^{62}$

54 Laura Barnett, "Canada's Approach to the Treaty-Making Process" (revised 2012), online: Library of Parliament Research Publications < http://www.parl.gc.ca/content/lop/researchpublications/2008-45-e.htm>.

55 For a more comprehensive account, see Malhotra \& Hansen, supra note 28 at 88.

56 [1999] 2 SCR 817.

57 Ibid at paras 70-71. Remarkably, the Court confirmed the transnational judicial dialogue theory of Waters to the extent that it cited decisions of New Zealand and Indian courts in reaching its conclusion on the use of international human rights law as an interpretive tool.

58 A more exhaustive treatment of these issues is Ravi Malhotra, "Karl Klare's Vision of Democratization in the Workplace and the Contradictory Evolution of Labour Law Jurisprudence in the Supreme Court of Canada" (2015) 45:2 Ottawa L Rev 303.

592001 SCC 94, [2001] 3 SCR 1016.

60 Ibid at para 27. The Court also referred to ILO Convention No 11, concerning the Rights of Association and Combination of Agricultural Workers, see ibid [pinpoint needed].

612007 SCC 27, [2007] 2 SCR 391 [BC Health].

62 Ibid at paras 69-72. The accuracy of the Court's understanding of ILO jurisprudence has been disputed but that question is beyond the scope of this paper. See Brian Langille, "The Freedom of Association Mess: How We Got into It and How We Can Get out of It" (2009) 54 McGill LJ 177 at 194-97. 
Finally, in Ontario (Attorney General) $v$ Fraser, ${ }^{63}$ a majority of the Court upheld the constitutionality of legislation, the Agricultural Employees Protection Act, 2002, ${ }^{64}$ specifically crafted by Ontario in response to the Supreme Court's earlier decision in Dunmore to provide some mode of recourse for agricultural workers. Unlike the decisions in Dunmore and B.C. Health, the Fraser Court concluded that there was no violation of the Charter in this particular case. ${ }^{65}$ Nevertheless, the Court majority reiterated its earlier view that Canada's international obligations support the view that some measure of collective bargaining was constitutionally protected. Writing for the majority, Chief Justice McLachlin and Justice LeBel specifically referred to ILO Convention No. $87 .{ }^{66}$

Moreover, to the extent that some of the content of the CRPD clearly amounts to customary international law, it may be regarded as common law provided that contradictory legislation has not been enacted. ${ }^{67}$ On the whole, then, the Canadian context has historically been more open to the use of international human rights in the disability law context and counsel would be well advised to make CRPD arguments where appropriate, notwithstanding the failure of the government to craft appropriate implementing legislation. While this may change if and when the United States Senate ratifies the $C R P D$, as of this writing, that day seems distant. Yet there has already been a small body of jurisprudence in both countries that has discussed, however fleetingly, the CRPD. In Part III, I consider how the limited Canadian and American jurisprudence to date has analyzed the $C R P D$.

\section{CANADIAN AND AMERICAN JURISPRUDENCE UNDER THE CRPD}

\section{A. Canadian Courts and Tribunals}

As of June 2015, a Quicklaw search generated eight decisions by Canadian courts which cite the $C R P D$. The decisions range from judicial reviews of rejections of immigration applications, to appeals from sentences in criminal convictions, to an appeal from a decision of a Taxicab Board denying the applicant a license. In addition, there is one unsuccessful allegation of disability discrimination before a human rights tribunal decision from Ontario which cites the $C R P D$. While these numbers are of course relatively low, two of the court decisions are from 2014, suggesting that perhaps we are in the infancy of $C R P D$ jurisprudence. ${ }^{68}$ It should also be noted that, of course, the CRPD is not necessarily the reason for the outcome. In some cases, the court is simply repeating the submissions of counsel but it remains remarkable that counsel are

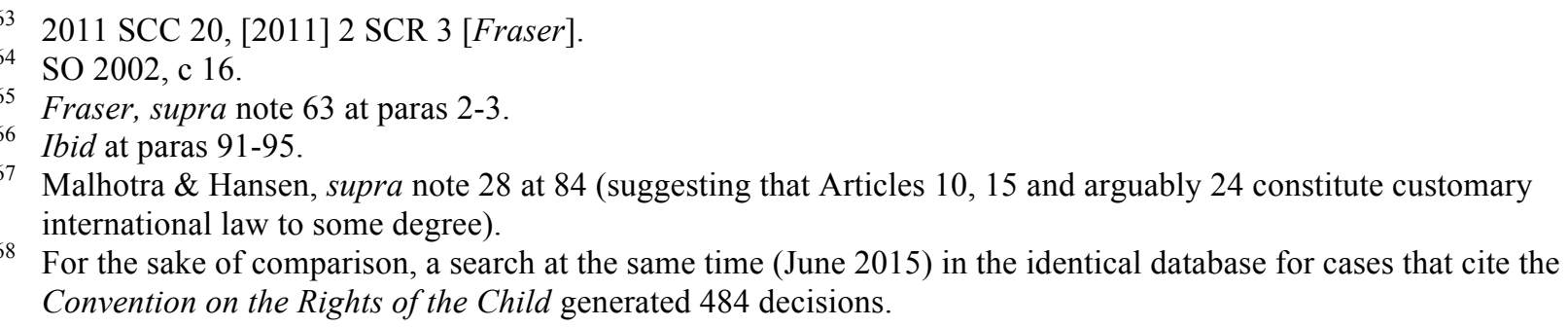


choosing to frame legal arguments around the CRPD. ${ }^{69}$ What follows is a brief commentary on the most important of these eight decisions.

In perhaps the most frequently cited of the Canadian decisions, Saporsantos Leobrera $v$ Canada $^{70}$ the Federal Court considered whether an application to seek judicial review of a decision denying the applicant's claim for admission to Canada on humanitarian and compassionate grounds should be allowed. The Court allowed the application for judicial review on the ground that salient information was wrongly removed from the applicant's file but our focus is on the CRPD arguments. ${ }^{71}$ The case concerned a Filipina Canadian woman who is a permanent resident and has a 23-year-old daughter with intellectual disabilities - the applicant. The daughter lived in the Philippines where she was cared for by her aging grandparents. When the mother immigrated to Canada, she omitted her daughter from her own immigration application on the advice of experts who were concerned the entire family might be barred from Canada on medical grounds. ${ }^{72}$ Consequently, the immigration officer decided that the applicant was barred from membership in the family class and could not be sponsored because of the omission. $^{73}$ The case turned on whether the daughter, who met the definition of a dependent child contained in section 2 of the Immigration and Refugee Protection Regulations [IRPR $]^{74}$ notwithstanding her age, ought to be deemed a child for the purposes of a humanitarian and compassionate grounds application seeking an exemption for medical admissibility pursuant to section 38(1) of the Immigration and Refugee Protection Act. ${ }^{75}$

The Court held that the definitions contained in the IRPR were not determinative of whether the applicant was a child for the purposes of a humanitarian and compassionate grounds application. ${ }^{76}$ In reaching this conclusion, the Court relied on both the Convention of the Rights of the Child and the CRPD which it noted distinguished between the rights of children with disabilities and adults with disabilities. ${ }^{77}$ Hence, the Court emphasized Article 7 of the $C R P D$ which establishes specific responsibilities for state parties with respect to children with

69 It should also be noted that by using judicial decisions as the source of research, one of course cannot capture arguments referring to the $C R P D$ made in factums.

702010 FC 587 [Saporsantos Leobrera].

71 Ibid at para 83 .

72 Ibid at paras 11-12. Unfortunately, such fears are warranted as Canada has a long history of excluding immigrants perceived as being a burden to the health care system. For an account of the early history and its eugenic basis, see Ena Chadha, “'Mentally Defectives' Not Welcome: Mental Disability In Canadian Immigration Law, 1859-1927” (2008) 28:1, online: Disability Studies Quarterly <http://dsqsds.org/article/view/67/67>.

73 Saporsantos Leobrera, supra note 70 at para 11.

$74 \mathrm{SOR} / 2002-227, \mathrm{~s} 2$.

75 SC 2001, c 27.

76 However, the application was allowed because the immigration officer was found to have improperly excluded relevant information about conditions for people with disabilities in the Philippines. See Saporsantos Leobrera, supra note 70 at paras $73-76$.

77 Ibid at paras 55-72. 
disabilities. $^{78}$ It also relied on Article 23 which distinguishes between children and adults in the context of a provision delineating rights with respect to marriage and the home. ${ }^{79}$

On the one hand, the Court honoured the values of the CRPD by making clear that adults and children are separate categories. A legal framework which automatically defines adults with disabilities as "dependent" risks reinforcing troubling and infantalizing stereotypes about people with disabilities. Yet, it is at least somewhat ironic that the CRPD has been used in a widely cited decision of the Federal Court to make it easier to deny humanitarian and compassionate grounds applications for people with disabilities seeking to immigrate to Canada. Given that the mother excluded her daughter with disabilities on her successful family class application because of well grounded fears of exclusion, it seems troubling that the CRPD ought to be used to facilitate denials of humanitarian and compassionate grounds. However, perhaps an identification of vulnerability is an inherent part of the category. Disability rights scholars have noted how people with disabilities must frequently emphasize vulnerability in order to qualify for social assistance benefits in ways that may not fully accord with their self-conception and principles of dignity. ${ }^{80}$

The Federal Court used the $C R P D$ in a very unusual way in another immigration decision, Bailey $v$ Canada. ${ }^{81}$ In Bailey, a sixty-year-old Jamaican man with a criminal history sought an exemption on humanitarian and compassionate grounds from the requirement that he apply for permanent residency while outside the country. ${ }^{82}$ The man was a quadriplegic and reliant on others for his personal care twenty-four hours a day, as a result of a beating he had received with a baseball bat for being a police informant in drug trafficking. He had lived outside of Jamaica for decades. ${ }^{83}$ The immigration officer denied his application because the officer concluded that Bailey had failed to demonstrate that he had established himself in Canada, had sufficient personal relationships or would face discrimination as a person with a disability if he were deported to Jamaica. ${ }^{84}$ On judicial review, the judge quashed the decision, because the research of the officer, which was largely reading web sites, was found to be deficient. ${ }^{85}$ Characterizing the officer's work as "bizarre", the judge noted that the officer's contention that Jamaican attitudes about disability were evolving was inadequate given that the applicant required round the clock care as a quadriplegic and the available facilities were totally inappropriate for his needs. ${ }^{86}$ However, what is interesting is that the applicant made submissions about the fact that although Jamaica had ratified the $C R P D$, it had not undertaken any steps for substantive

78 CRPD, supra note 1 at Art 7.

79 Ibid at Art 23.

80 For a lucid account of the relationship between rights and identity in the context of the $A D A$, see David M Engel \& Frank W Munger, Rights of Inclusion: Law and Identity in the Life Stories of Americans with Disabilities (Chicago: University of Chicago Press, 2003).

812014 FC 315 [Bailey]. For another take on Bailey, see Mark C Weber, "Immigration and Disability in the United States and Canada" in this volume.

82 Bailey, supra note 81 at paras 1-2.

83 Ibid at para 2.

84 Ibid at para 6-16.

85 Ibid at paras 59-63 (noting, inter alia, that the Jamaican facilities identified by the immigration officer required residents to engage in farm work impossible for a quadriplegic).

86 Ibid at paras 62-64. 
compliance. ${ }^{87}$ While it cannot be said the CRPD argument was determinative in this case, it is likely that future litigants with disabilities facing deportation will raise the failure of their home countries to comply with the CRPD as one part of humanitarian and compassionate ground applications. How this evolves remains to be seen.

A third decision that engages with the CRPD is a criminal law matter decided by the Alberta Court of Appeal, R. v Myette. ${ }^{88}$ The accused was an Aboriginal blind man and guide dog user convicted of sexual assault and assault of his female roommate. The only issue on appeal was the sentence. The trial judge had given the defendant a suspended sentence of eighteen months, in part, because of the inability of the penitentiary system to accommodate his impairments. ${ }^{89}$ She specifically relied on the liberty rights protected by Article 14 of the CRPD. ${ }^{90}$ The prison authorities had made clear that the convict's guide dog could not be accommodated in a prison setting. ${ }^{91}$

A majority of the Court of Appeal allowed the Crown's appeal. The majority found that the sentence was unfit and that issues of accommodations of prison inmates ought to be left to the prison authorities. The majority rejected the trial judge's finding that the CRPD had been violated because of a lack of specific policies for blind inmates. The majority instead accepted the evidence that accommodations could be made and that there historically had been virtually no blind inmates. ${ }^{92}$ The majority concluded that, given the seriousness of the offence, the trial judge should have interpreted the sentencing provision in the Criminal Code to require a custodial sentence of eighteen months, with a reduction to account for the defendant's impairments. In reaching such a conclusion, the trial judge should have reached an interpretation of the sentencing provision that complied with Canada's responsibilities under the CRPD. ${ }^{93}$

In dissent, Martin J.A. would have upheld the trial judge's sentence because of the harsh impact of prison on a blind person. However, the dissent did not address the CRPD issue. ${ }^{94}$ The decision in Myette is in some respects similar to Saporsantos Leobrera. The idea of treating all convicted persons similarly for sentencing purposes and leaving the provision of disability accommodations to prison authorities is compelling logic. The seriousness of the offence in this case and its violent nature also makes sentencing a real challenge. However, the record of prison authorities in dealing with people with psychiatric disabilities who are more commonly incarcerated raises real questions about the likelihood of significant accommodations for prisoners actually being made in an overcrowded and underfunded system. ${ }^{95}$

\footnotetext{
Ibid at para 40.

882013 ABCA 371, rev'g 2013 ABPC 89. Both courts considered the CRPD and so I have counted them separately in tabulating total citations to the $C R P D$ in Canadian courts.

Ibid at paras 1-12.

Ibid at para 16.

Ibid at para 8.

Ibid at paras 33-36.

Ibid at paras 34-39.

Ibid at paras 43-50.

On the incarceration of people with disabilities, see generally Ben-Moshe, Chapman \& Carey, supra note 23.
} 
A more conventional and straightforward use of the $C R P D$ is its mere mention by counsel such as counsel for the intervener, CCD, in Canada (National Capital Commission) v Brown. ${ }^{96}$ In Brown, the Federal Court considered a judicial review application of a decision of the Canadian Human Rights Tribunal finding that the National Capital Commission and Public Works had violated Brown's human rights under the Canadian Human Rights Act by failing to provide accommodations to allow him to access the York Street Steps in Ottawa. Instead, Brown, a wheelchair user, had to be separated from his friends in order to access an elevator some 130 metres away. ${ }^{97}$ He was effectively making a relatively novel claim for adaptation of the exterior physical environment to include people with disabilities in accordance with principles of Universal Design. ${ }^{98}$ The Tribunal had ruled that the respondents had violated Brown's rights by failing to make the steps universally accessible and by failing to consult with him, an obligation they found existed as part of their duty to accommodate Brown's disability. ${ }^{99}$ On judicial review, Justice Noel of the Federal Court quashed the decision, ruling that there was no duty to consult and the accommodation had to be considered globally. ${ }^{100}$ For our purposes, what is interesting is that CCD relied on the CRPD to argue that the duty to accommodate included a duty to consult. ${ }^{101}$ In Brown, the underlying facts were challenging because many observers might see the claim as frivolous, especially as Canadian cities are replete with so many accessibility barriers. However, it may be that such arguments would be successful in a stronger case and the $C R P D$ could effectively bolster a rethinking of what accessibility in the built environment means.

In Tanudjaja $v$ Canada (Attorney General), ${ }^{102}$ the Ontario Superior Court of Justice considered motions for various advocacy organizations to be granted intervener status in a motion to dismiss a landmark application alleging that governments violated section 7 and 15 of the Charter in denying affordable housing to low income people. The Court ruled that one of the proposed interveners, the Amnesty Coalition, ought to be granted intervener status to address how specified international treaties, including the CRPD, affect an analysis of section 7 and

962008 FC 733 [Brown]. I disclose that I serve on the Human Rights Committee of the Council of Canadians with Disabilities, an intervener in Brown.

97 Ibid at para 1. On further appeal, the Federal Court of Appeal in brief reasons unanimously allowed an appeal of the Federal Court's decision and sent the case back to be heard by a differently constituted tribunal. See Canadian Human Rights Commission v National Capital Commission, 2009 FCA 273. However, as this decision does not address the CRPD, I will not discuss it here.

98 For a critical overview of Universal Design, see Aimi Hamraie, "Universal Design Research as a New Materialist Practice” (2012) 32:4, online: Disability Studies Quarterly <http://dsqsds.org/article/view/3246/3185>. See also Robert Imrie, "Universalism, Universal Design and Equitable Access to the Built Environment" (2012) 34:10 Disability \& Rehabilitation 873.

99 Brown, supra note 96 at para 60.

$100 \mathrm{Ibid}$ at para 148. Unfortunately, despite denials by the Court, this reasoning on assessing the global environment embraces the kind of flawed logic that the majority of the Supreme Court of Canada rejected in Council of Canadians with Disabilities v Via Rail. See 2007 SCC 15, [2007] 1 SCR 650.

101 Brown, supra note 96 at para 114.

1022013 ONSC 1878. This case is the only ongoing Canadian litigation discussed in this paper. 
15. ${ }^{103}$ In a subsequent decision, the Court ruled in favour of a motion to dismiss the case on the ground that it was plain and obvious it could not succeed. ${ }^{104}$

Finally, turning to decisions of Canadian administrative tribunals, in Hinze $v$ Great Blue Heron Casino, ${ }^{105}$ the Human Rights Tribunal of Ontario applied the Preamble of the CRPD in the context of an allegation that the employer's dismissal of Hinze, a housekeeping supervisor at the Casino's Facility Maintenance department, violated the province's Human Rights Code by discriminating against him on the basis of disability. Robert Hinze had a history of medical issues with his leg that had required him in the past to take extensive time off and work on a modified schedule. ${ }^{106}$ However, at the time of his dismissal, Hinze had been back at work for some time and was no longer receiving any accommodations. ${ }^{107}$ The Member ruled that on the facts, the applicant did not meet the definition of a person with a disability. In the Member's view, a correct reading of the case law and of the social model requires more than a past history of disability, notwithstanding the applicant's submissions that he still had edema and pain in his leg. ${ }^{108}$ This decision seems to apply a strict standard as to what constitutes a disability. However, it also embraces the idea that the Preamble of the CRPD endorses the social model. ${ }^{109}$ This holds out promise for future cases even if the outcome is disappointing on the facts here. Like in some other cases, it may be that the factual matrix was too difficult to overcome. The evidence in the case was that the employer had dismissed Hinze at least in part because he was contradicting his employer's policy of prohibiting loans to subordinate employees. ${ }^{110}$ Hinze loaned over $\$ 2,000$ to three staff members on his team and used the employer's computer and letterhead to prepare documentation relating to repayment of the loans. ${ }^{111}$ The employer took the position that the dismissal was justified because it had a clear policy on improper use of electronic equipment and a conflict of interest policy which prohibited financial transactions unrelated to the employer with subordinate employees whom Hinze managed. ${ }^{12}$ Given the apparent misconduct of Hinze, his application was dismissed.

Another administrative law decision citing the $C R P D$ is the interim decision of the Human Rights Tribunal of Ontario in Kacan $v$ Ontario Public Service Employees Union. ${ }^{113}$ In this unusual case, the applicant, a woman with intellectual disabilities, alleged that her rights were infringed under the Human Rights Code when the union representing her personal support workers picketed her home in the context of a legal strike. ${ }^{114}$ In an interim decision, the Tribunal

103 Ibid at para 52.

104 Tanudjaja v Canada (Attorney General), 2013 ONSC 5410, aff'd 2014 ONCA 852 (Justice Feldman dissenting), leave to appeal to SCC denied June 25, 2015.

1052011 HRTO 93.

106 Ibid at paras 5-13.

107 Ibid at para 25.

108 Ibid at para 13.

109 Ibid at para. 21.

110 Ibid at para. 9.

111 Ibid.

112 Ibid at para 11-12.

1132010 HRTO 795. There appear to be only two Canadian administrative law decisions that cite the CRPD to date. I thank Megan Rusciano for bringing this case to my attention.

114 Ibid at para 1. 
adjudicator considered an objection by the union that the Tribunal should determine whether a litigation guardian was required given uncertainty about the mental capacity of the applicant. ${ }^{115}$ The adjudicator concluded that the then new section 34(5) of the Human Rights Code authorizes a person to bring an application on behalf of another individual without acting as that person's legal counsel. ${ }^{116}$ On the question of capacity, the adjudicator ruled that the claimant with a disability merely has to be able to understand information relevant to making the decision to delegate the complex day to day management of the litigation to the applicant. ${ }^{177}$ In so ruling, he referred to the Supreme Court of Canada's decision in Baker ${ }^{118}$ for the proposition that international human rights law may help inform a contextual understanding of statutory interpretation and judicial review. He then invokes Article 12 of the CRPD, which requires state parties to ensure people with disabilities have the requisite supports to exercise their rights before the law, to ground his analysis on capacity, while recognizing the need for appropriate safeguards. ${ }^{119}$ On the facts, the adjudicator concluded that these general principles would inform the interim decision and the parties could make further submissions at a later date. ${ }^{120}$

What can we discern from this brief foray into the world of international human rights law? By and large, despite ratification, the CRPD has yet to make a significant contribution with respect to cutting edge disability rights law cases in Canada. Indeed, only one of the eight court decisions, Brown, could be truly considered a matter directly related to physical accessibility. Perhaps the most positive impact so far is the possibility that the CRPD will be more seriously considered when considering the deportation of immigrants with disabilities to countries that have failed to comply with their obligations under the CRPD. Yet, the openness which Canadian courts have shown to a judicial dialogue with the language of the CRPD holds out the possibilities of further developments when an appropriate case occurs.

\section{B. American Courts}

As of June 2015, a Westlaw search produced five significant American court decisions that cite the $C R P D$ in some respect. The most striking thing about this figure is that this is fewer than the Canadian number, notwithstanding a population in the United States which is ten times greater than in Canada. The fact that the citation count is (slightly) lower suggests the antipathy of some American courts to the use of international law. ${ }^{121}$ It likely also reflects the fact that the Senate has yet to ratify the CRPD and counsel, perhaps correctly, conclude that they should focus their limited time and energy elsewhere.

Perhaps the most dramatic American decision to cite the CRPD is Re Guardianship of Dameris L. ${ }^{122}$ In Dameris, the New York Surrogate's Court explored the constitutionality of a

${ }^{115}$ Ibid at para 2.

${ }^{116}$ Ibid at para 5.

117 Ibid at para 21.

118 Baker, supra note 56.

119 Ibid at para 23.

${ }^{120} \mathrm{Ibid}$ at para 26.

${ }^{121}$ See supra note 46, and accompanying text (describing how Justices of the United States Supreme Court have received death threats when citing foreign jurisdictions).

122 (2012) 38 Misc 3d 570, online: <http://caselaw.findlaw.com/ny-surrogates-court/1619828.html>. 
provision of the Surrogate's Court Procedure Act. The case concerned a petition to terminate guardianship with respect to an adult woman, Dameris, labelled as having intellectual disabilities and who had married a man with a history of alcohol and drug abuse, mental health issues as well as criminality. Together, they had two children and the family was thriving with appropriate supports. Dameris was found capable of making choices about her medical care such as consenting to a tubal ligation. ${ }^{123}$ However, the Court had previously approved a guardianship application making the mother and husband of Dameris her co-guardians. ${ }^{124}$ In this case, the Court ruled that guardianship would only be approved where it can be shown it is the least restrictive alternative so as to minimally infringe the liberty of the individual, while at the same time protecting the individual and the community. ${ }^{125}$ It also stated that substitute decision making was not consistent with the guarantees with respect to equal protection before the law and legal capacity contained in Article 12 of the CRPD. ${ }^{126}$ It further stated that the CRPD was persuasive weight for the principle of supported decision making and the Surrogate's Court Procedure Act should be read in a manner that is consistent with the CRPD and the petitioner's substantial due process rights. ${ }^{127}$ This is a welcome ruling and somewhat surprising given the fact the $C R P D$ remains unratified in the United States. It suggests a willingness on the part of the court to be creative in protecting the rights of people with intellectual disabilities.

An earlier decision from the New York Surrogate's Court is also of interest. This decision, Re Mark C.H. ${ }^{128}$ concerned the monitoring of the guardianship of a twenty-one year old man with intellectual disabilities. He and his brother had been adopted by a wealthy woman. ${ }^{129}$ She later died of cancer and left a trust fund worth nearly three million dollars for his care. However, the Court discovered that the trustee had never visited the beneficiary and never spent any money whatsoever to improve his quality of life. ${ }^{130}$ The Court specifically cited Article 12(4) of the $C R P D$ for the proposition that guardianships regulated under the parens patriae power in New York State law must be subject to regular review to prevent abuses. ${ }^{131}$ The Court even commented that despite the fact the Senate has not yet ratified the CRPD, the Vienna Convention on the Law of Treaties nevertheless prohibited signatories from acting in a manner which would defeat the CRPD's object and purpose. ${ }^{132}$ As in Dameris, the Court found that the international adoption of disability rights ought to be accorded persuasive weight in the interpretation of domestic law. ${ }^{133}$ Interestingly, both Dameris and Mark C.H. were decided by Judge Kristin

\footnotetext{
23 Ibid at 571-76.

124 Ibid at 573.

125 Ibid at 577.

126 Ibid at 579.

127 Ibid at 580 citing Lawrence $v$ Texas (2003) 539 US 558.

12828 Misc 3d 765, online: New York State Law Reporting Bureau $<$ http://www.courts.state.ny.us/Reporter/3dseries/2010/2010_20156.htm\#4CASE $>$.

129 Ibid at 766.

${ }^{130}$ Ibid at 767.

131 Ibid at 784-85.

132 Ibid at 785 .

133 Ibid at 786 (citing international adoption of right of periodic review of burdens on individual liberty).
} 
Booth Glen, a former academic who clearly has an interest in social justice and has published on the question of capacity. ${ }^{134}$

Of course, other courts have been dismissive in claims of CRPD breaches. In Knapp $v$ Cate ${ }^{135}$ the United States District Court for the Eastern District of California dismissed the supplemental claims of a California prisoner who alleged that his constitutional rights were violated because of the prison's refusal to allow him single cell status. The prisoner argued that the actions of various prison officials denying him single cell status were in retaliation for his litigious conduct and the expression of his First Amendment rights. ${ }^{136}$ The Court rapidly dismissed the claims because the allegations were insufficient to state a plausible claim. ${ }^{137}$

\section{SOME CONCLUSIONS}

This paper has explored how the United Nations Convention on the Rights of Persons with Disabilities has begun to have an impact on Canadian and American law and consequently people with disabilities. I have also suggested how, despite the antipathy in some quarters to foreign law in the United States, the Americans with Disabilities Act has revolutionized thinking in many countries about how we regard the lives of people with disabilities. While change is painfully slow, transnational judicial dialogue is likely to expand in coming years as courts, administrative agencies and non-governmental actors increasingly talk across borders. The important work of Koh and Waters provides a framework and methodology in which to better understand these transnational relationships. The rulings discussing the CRPD to date in the two countries are somewhat surprising. While it is not unexpected that there are very few American rulings, two of the decisions are surprisingly robust in supporting the rights of people with disabilities in the context of protecting people with intellectual disabilities. It is hard to say whether that logic would carry forward in other contexts. On the other hand, while more numerous, at least some of the Canadian decisions promote outcomes that are at least arguably counter-productive to the goals of social justice. It is a real irony to see the CRPD used to facilitate denials of compassionate and humanitarian applications by people with disabilities. The $C R P D$ case law is of course in its infancy and little can be concluded from such a small sample size. As the case law accumulates, further research will need to be done to determine what the trends are and how advocates can continue to promote social justice in the courtroom and outside it.

${ }^{134}$ See Kristin Booth Glen, "Changing Paradigms: Mental Capacity, Legal Capacity, Guardianship, and Beyond" (2012-13) 44 Colum HRL Rev 93.

135 F Supp 2d 2011 WL 5416342, available online: US Government Publishing Office

$<$ http://www.gpo.gov/fdsys/pkg/USCOURTS-caed-1_08-cv-01779/pdf/USCOURTS-caed-1_08-cv-0177917.pdf $>$.

${ }^{136}$ Ibid at $4-5$.

${ }^{137}$ Ibid. Similarly, the United States District Court for the District of New Jersey dismissed, with no discussion, actions by an injured worker against his employer and union as well as the workers' compensation system and he made bare assertions that the $C R P D$ was violated in the handling of his claim for disability benefits. See Townsend $v$ New Jersey Transit and Amalgamated Transit Union, F Supp 2d 2010 WL 3883304 (D NJ) and Townsend v Calderone, F Supp 2d 2010 WL 1999588 (D NJ). 